\title{
Library and Information Science in the USA and Iran
}

\author{
Dr. Michel Nguessan \\ Associate Professor of Library and Information Science, Governors State University \\ cangaley@yahoo.com \\ Dr. Shima Moradi (Corresponding author) \\ Faculty member of Scientometrics Dept., National Research Institute for Science Policy \\ (NRISP) \\ moradi@nrisp.ac.ir
}

\begin{abstract}
In a context of global mobility of skilled professionals, this is a comparative study of library science education and librarianship in the USA and Iran. The study attempts to determine how education and professional skills may transfer from one country to another. Historically, the USA and Iran are two different major centers of development of knowledge, science and technology and culture. Each one of these two countries developed its own system of general education and library science education and professional practice. This study investigates the definition of the librarian profession, historical perspectives, types of librarians and librarian-related positions, the initial academic training of librarian (schools, duration, curriculum, and accreditation), daily activities of librarians, continuing education, and opportunities and challenges of the profession in each country. The qualitative research methods was selected to conduct this study. This investigation leads to a comparative analysis pointing out similarities and differences. The first part of the paper present historical perspectives and library science education and librarianship. The second part of the paper presents contemporary library science education and librarianship in each country. The last part of the paper is a comparative critical discussion of both systems. This study concludes that, even though both systems are different, with the globalization of knowledge, education, and communications, under certain circumstances, one could consider a librarian "qualified" to practice across the border.
\end{abstract}

Contributions: The comparative investigation of LIS profession and education have been conducted for the first time.

Keywords: Library and Information Sciences, comparative study, education, profession 


\section{Introduction}

This is a comparative study of librarianship and Library Science education that tries to provide tools for proper assessment of Iranian degrees in the USA and vice-versa. The selection of these two countries got the roots in the fact that the American and English professional librarians had supported Iranian librarians founding of the Iranian librarians Association, designing librarianship curriculum, as well as launching library science bachelor, and master in Tehran University through Fulbright program during 1965-1966. Moreover, the Iranian librarianship was largely influenced by the scientific activities of the Iranian Librarians Association during 1966, as they had graduated in the United States (Hopkins, 1975).

The study investigates professional librarians' academic qualifications offered by Iranian institutions and compares them to similar degrees offered in the USA. The question the study is trying to address is: how to assess the quality of LIS education and degrees from Iranian institutions for professional librarian employment in the USA? In Iran, LIS education offers traditional bachelors and graduate degrees (Master and Ph.D.) in the field. By contrast, American LIS education for professional librarianship is standardized and unified in a North American context under the ALA accreditation label for the Masters' degree even though a few institutions offer bachelors' degrees that do not give access to title of professional librarian without further education. . It is also worth mentioning that differences in resources and the digital/technology divide between the USA and Iran has a differential impact on programs and resources offering in both regions. The paper is a qualitative analysis of primary and secondary source data collected about LIS education institutions and programs in both regions.

After the research methodology and the literature review sections, the study presents LIS education in the USA and Iran in an attempt to establish equivalencies between the different LIS education systems. The last part of the paper focusses on findings, discussion about how the quality of LIS education can be improved. This paper is a contribution to comparative and international LIS education research.

\section{RESEARCH DESIGN AND DATA COLLECTION}

We selected qualitative research methods to conduct this study. This qualitative approach builds on many written and/or electronic resources on the topic. The choice of qualitative methods can be explained by the importance of the national, social and cultural factors in the field of library and information science. The qualitative research methodology is particularly suitable to collect data in an environment where human factors, attitudes and behaviors and cultural factors are critical elements. To collect data for this study, the researchers performed a search for institutions, curricula, policy and regulations in the field of library and information science in the USA and in Iran. On both sides, the researchers collected information about LIS schools, LIS accreditation institutions and other governmental and non-governmental institutions regulating education, qualifications and professional practice in the field of LIS. On the USA, the researchers reviewed LIS education in selected schools such as the ones at the University of Illinois at Urbana Champaign and the University of Michigan in Ann Arbor. They also collected information about accreditation and professional practices from American Library Association sources. On the Iranian side, two ministries of Science, Research and Technology and Health and Medical Education are responsible to plan for every discipline like LIS and Medical LIS by assigning the Planning Committee for education in LIS (Azad, 1987) and High Council for Medical Planning to revise and suggest new curriculum in this field for all schools nationwide and improve the impression of this career in the society. Moreover, the information about LIS education in Iran was collected from these committees and related researches. All the documentary sources were reviewed for the analysis. 


\section{Literature Review}

There is a significant literature comparing LIS education and professional practice in the USA and Iran. These studies tend to focus more on specialties/minors rather than on the whole program. Lila Mortezaie and Nader Naghshineh (2002) compared LIS education programs in UK, USA, India and Iran. This paper that compared LIS program development in developed countries versus developing countries conclude that:

The findings support no clear conclusion other than the fact that there is a widening chasm between LIS education in developed countries and those in developing countries. Without any significant restructuring, the LIS program in Iran will provide little in the way of riding out the rapid transition that the field is currently experiencing at regular interval (Mortezaie \& Nader Naghshineh, 2002).

The conclusion of this study ((Mortezaie \& Nader Naghshineh, 2002) suggests that in order to improve LIS education in Iran, it is important to: introduce competiveness within the curricula and academic management; make LIS education multidisciplinary; to establish independent LIS schools; to abandon centralized planning from the Ministry; allow LIS schools to engage constructive and progressive program planning. Fattahi (2005) conducted a study on the LIS curriculum in USA, UK, Canada, Australia and India to find similarity with Iran's and suggested two minors in Information management and Information technology management based on the current information needs of the country.

In 2011, Alimohammadi found strong similarity between LIS Ph.D. curriculum in Iran, USA and Canada and Mansourian (2011) also linked LIS minors/specialties in UK, USA, Canada and Australia and pointed out the variety and diversity of these programs due to the specialization and interdisciplinary nature of LIS. Moreover, Taheri and Alaee Arani (2012) focused on LIS specialties/minors in USA, UK, Canada, and Iran, and their effectiveness on scientific productions at the international level. They found out that the multiplicity of specialties/minors were different in different countries and have a direct effect in their productivity. They also believed that these specialties/minors have to be created on the basis of the community needs of that society/country and they reflects the maturity of this field.

On the other hand, there is an abundance of literature on different aspects of the topic that helped define and refine this study, comprehensively. General literature on comparative education helped build a good understanding of this field and determine how our study fits in. Major research works in comparative education were considered including Comparative Method in Education (Bereday, 1964), Comparative Education (Nicholas, 1967), Comparative Education: Some Considerations of Method (Holmes, 1981), Comparative and International Research in Education: Globalisation, context and difference (Crossley and Watson, 2003), Comparative Education: The Construction of a Field (Manzon, 2011), Theories and Methods in Comparative Education (Schriewer and Holmes, 1988), Social Cartography: Mapping Ways of Seeing Social and Educational Change (Paulston, 2000), Toward a Science of Comparative Education (Noah and Eckstein, 1969), "Comparative Education: The Dialectic of the Global and the Local (Arnoye and Torres, 2007)", "Globalization and Educational Reform: What Planners Need to Know" (Carnoy, 1999), “Comparative and International Education." (Ginsburg and Price-Rom, 2008, In Encyclopedia of the Social and Cultural Foundations of Education); "Reconceptualising comparative and international education (Crossley, 1999). However, there are some comparative studies on library and information education focused on different regions as West Africa (Akinyotu, 1976), Tanzania and Jordan (Bouazza\& Nimer, 1986), European Union (Juznic \& Badovinac, 2005), developing countries (Johnson, 2007), United State and Asian countries (Liu \& Cheng,2008) referring to the courses, curriculum, educational goals, models, career prestige, librarian skills.

Literature on library and information science education in both countries was critical for developing a good understanding of the topic. 


\section{LIS education in the USA and in Iran}

\subsection{LIS Education in the USA}

LIS education which is responsibility of many higher education institutions is regulated by the American Library Association through its ALA label for academic degrees. In fact,

\footnotetext{
"The American Library Association (ALA) is the oldest and largest library association in the world. Founded on October 6, 1876 during the Centennial Exposition in Philadelphia, the mission of ALA is "to provide leadership for the development, promotion and improvement of library and information services and the profession of librarianship in order to enhance learning and ensure access to information for all." (American Library Association, 2018).
}

The reference professional degree in the USA is the master's degree. This reference degree is the minimum qualification to enter the field of LIS and a professional librarian. As the ALA website states:

"In 1951 the new Standards for Accreditation were approved by ALA Council, stating that that the professional program should encompass a minimum of five years of study beyond secondary school and should lead to a master's degree. A master's degree in library science (MLS), preferably from an American Library Association (ALA) accredited program, is necessary for most librarian positions in most public, academic, and special libraries. School librarians may not need an MLS but must meet state teaching requirements." (American Library Association, 2018).

The ALA defined core competences in 2008 for librarianship that serve as guidelines for curriculum development by different academic institutions. The ALA states that:

"In the United States and Canada, a professional librarian normally has a one or two-year master's degree in library and information science, library science or information science with abbreviations such as MLS, MSLS, MIS, MS-LIS, MISt, MI, MLIS, or MILS. (...) Many, if not most, academic librarians also have a second, subject-based master's degree.” (American Library Association, 2018).

The core competences are defined in the following areas: 1) Foundations of the Profession, 2) Information Resources, 3) Organization of Recorded Knowledge and Information, 4) Technological Knowledge and Skills, 5) Reference and User Services, 6) Research, 7) Continuing Education and Lifelong Learning, 8) Administration and Management.

It clearly appears that LIS education is a graduate, master's level education for students already possessing an undergraduate degree in any other field. This American ALA standard has been adopted in Canada, making this education a kind of North American norm that is appreciated not only in North America, but in other regions of the world since several academic institutions in some non-North American countries advertised jobs with ALA degree requirements.

\subsection{LIS Education in Iran}

\section{Pre-Revolution}

It is important to distinguish two periods in LIS education in Iran: pre-revolution and postrevolution time. The pre-revolutionary time starts in antiquity since professional practice and education in LIS represent a long tradition that goes back to the Achaemenes period (640 BC-338 BC) and the Sassanid period (242 BC-31 BC) (Hayati, 2004a) with distinguished historical libraries. In 637 AD, after the Muslim conquest of Persia, royal libraries were replaced by school, academic, and personal/individual libraries which opened their doors to the public (Rahadoust, 2008). The nineteenth century brought some new developments in LIS practice and education during the Qajar rule (1779-1926) mirroring the growth 
of librarianship in the United Kingdom and the United States of America. However, access to this type of libraries was limited to the King and the Qajar court.

Modern LIS education and librarianship actually started with the rule of Pahlavi I (1925-1941), along with technical, economic and cultural infrastructures developments. During this period, the Ministry of Culture created the condition for the development of the Iran National Library (Alawi, 2002). In the meantime, some American institutes as well as UNESCO were funded Short term courses in LIS during 1952 to 1965, which found not easy to apply according to the differences between libraries in USA and Iran. Furthermore, the quality of their courses and their graduates was not such that they could manage brand new established academic libraries. Hence, it had leaded to the establishment of a college in Iran, along with dispatching students abroad (Hayati, 1996:149). Formal education in LIS started in 1938 with some training courses at the University of Tehran-Danesh Sara-e Aali (Kiani, 1970; Afshar, 1970; Kiani \& khouzestani, 1997; and Ebrami, 1975). Librarianship and LIS development in prerevolutionary Iran were also related to an agreement between the University of Tehran and the US Fulbright Commission which used to send at least one LIS academic professor annually to work in Iran. The first formal degree (Bachelor's) program started in Library Science started during the academic year 1964-1965 at the University of Tehran with Professor Alice Lohrer from the University of Illinois at Urbana-Champaign. A Master's program was established at the same university in 1966. The University of Tabriz started a Bachelor program in LIS in 1966 and a master's degree program two years later. These two institutions were followed by other universities (Shiraz, Jondi Shapoor and Al-Zahra) between 1974 and 1977.

\section{Post-Revolution}

In terms of education, after the Islamic Revolution in 1979, when universities reopened in 1982, government institutions such as the Supreme Council of Educational Planning, Ministry of Science took charge of the development of LIS programs and curricula. With the integration of the Library Services Center in the National Library, national cataloging and bibliographic tools were developed with more systematic scientific principles. The Planning Committee for education in LIS was launched to educate librarians to apply modern information technology tools (Azad, 1987; Faraj Pahlou, 1994; Dayyani, 2010; Zahir Hayati, 2004 a; Kilivand, 1999; Mohammadi, 1999). In 1986, new minors were developed in LIS in academic, public, school Libraries, and information sciences. A renovated Bachelor's degree with a new title was launched in 1987. In 1990, six minors were developed within the Bachelors' degree program. The first doctoral (PhD) program in LIS was developed in 1991 at the Islamic Azad University, a science and research branch of the University of Tehran. In 2006, two minors were developed within this $\mathrm{PhD}$ program in management of information technology and information management. Between 2006 and 2015, several minors were developed within the master degrees programs in information management, Information technology management, public library studies, academic library management, Information Management, information and Knowledge, scientometrics, manuscripts management and organization of manuscripts and archival studies. The tendency was to create new minors and specialties can meet the changing needs of society and play a significant role in scientific development (Mortazai, 1998). At the beginning of 1999, 24 library and information science departments were in charge of training librarians in Iran for the following degrees: Associate, Bachelor, Master, and Ph.D. Curricula were developed by the Supreme Council of Educational Planning (2012-2014) that made the English language a second language for students in LIS with the choice of another/third language French, German and Arabic.

The Bachelor's degree program provided courses in Libraries and Information Centers Management, Research Methodology and Reporting, Information and Communication Basics, Internet Application in Libraries, Statistics and Probabilities in Library and Information Science, Programming applications, Database Designing, Publishing Industry, Indexing, Electronic \& printed periodicals, History of developments in libraries, Resource Acquisition, Resource Organization 1 \& 2, Reference Resources-General $1 \& 2$, Reference Resources-Specialized $1 \& 2$, Reference principles, Library Building \& Equipment, Material and references for children, library \& Information sciences principals, 3 courses for internship, and Final Project. On the other hand, the Master's degree program provided courses: Scientometrics Principals, Application of Inferential Statistics in Scientometrics, National and international Databases in Scientometrics, the Architecture of Scientometrics databases, STI Systems evaluation, History of Philosophy, Science mapping, Sociology of Scholarly Communication, 
Webometrics, Research Methodology, Research Seminar, and thesis. It is also worth mentioning that several revisions of LIS curriculum by the relevant committee at the Ministry of Science, Research and Technology led to title revision twice from "librarianship" to "library and information science", and finally to the last title of: "Knowledge and information science" in 2012.

For career and professional practice, beyond academic education, librarians in Iran manage knowledge and information by creating and maintaining dynamic collections in various types of libraries. There are university libraries in all public, government and private colleges and universities. However, professional librarian positions in Iran are not always filled with LIS graduated in every institution even though this is an attempt to establish a LIS degree as a requirement for librarian jobs. A solution to this problem is the creation of new programs for LIS masters with specialties in in Information Management, Information Technology Management, and Scientometrics.

\section{Findings and Discussion}

\subsection{Findings}

Comparing to Iran, the USA has a longer tradition of librarianship and formal library science education. The American library association was created in 1876 while the first formal LIS degree in Iran was created in 1964-1965. In the USA, the tradition, and the cultural and political environment are very supportive of formal LIS education. Librarianship and library science education are highly valued in a country with thousands of librarians in academia, in communities and in the corporate world. It is worth noting that in the USA, no undergraduate degree gives access to the status of professional librarian. Instead, you have a graduate level education with a master's degree after a bachelor's degree in any field. Building LIS education in an undergraduate degree in another field allows the aspiring library to build subject expertise right from the beginning. For academic career as a librarian, most university requires a second master's degree in a subject field. This additional requirement allows the librarian to strengthen his/her expertise in in his/her subject area or to even add another subject area. This is therefore an additional opportunity for subject specialization. In the USA, librarians in several universities have the status of faculty members. LIS education in the USA is provided in a highly development educational system with hundreds of LIS schools collaborating and competing to provide the best to students. LIS educational institutions and programs are relatively well funded and evolve in a highly advanced information technology environment. This education is guided and supported by very high standards development by the American Library Association. In fact, the ALA label for LIS degrees in the USA is a label of excellence and prestige not only in North America, but also in other parts of the world.

The LIS profession has started long time ago in Iran comparing to other countries in the world. Their educational system provides LIS education at the undergraduate level with a bachelor's degree in four minors/specialties Medical, Humanities \& Social Sciences, engineering and Pure Sciences. One can be a librarian with a bachelor's degree in LIS. Master's degrees also exist as additional/advanced qualifications without being a requirement to be a professional librarian. The minors/specialties are Information Management, Information Technology Management, Public Library Studies, Academic Library Management, Information Management, information and Knowledge, Scientometrics ${ }^{1}$, manuscripts management and organization of 
manuscripts and archival studies. Obviously, one can also be a librarian with a master's degree in LIS after an undergraduate degree in LIS or in another field. In caser somebody's undergraduate is in LIS, and he/she becomes a librarian, he/she does have subject expertise in the above mentioned minors if he/she has a graduate degree in LIS after an undergraduate degree in another field, this other field gives him/her a subject expertise which is highly recommended for master candidates these days to meet the needs of community.

As for job seeking, it is worthy to mention that, with the increasing importance of Science, technology, and Innovation, the scientometrics department and offices have been launched in universities and organizations to evaluate scientific productivity and impact of universities and researchers' recently which opens new horizons to the LIS master graduates. In the meantime, librarians can also work in the scholarly communications offices of universities, institutes and ministries like Iranian Research Institute for Information Science and Technology (IranDoc) ${ }^{1}$. However, less economic, technological and pedagogical resources, especially in Farsi, make it more challenging to provide and acquire adequate LIS education. This is the reason LIS faculties and experts try their best to provide more textbooks and resources in Farsi to meet this important need.

\subsection{Discussion}

The key question is whether a LIS education and/or professional practice in Iran is equivalent or at least comparable to similar education and practice in the USA. It is not realistic to provide a simplistic answer to this question. Differences in cultural, political and economic environment and education history translate into major difference in terms of degree and experience received on both sides. In Iran, librarianship and LIS education face many challenges inherent to education systems developing countries. While it is legitimate to provide LIS education in the national language of Iran (Farsi), this language may represent a limitation from international perspective. LIS graduate who do have an adequate mastery of the English language and other international language are not limited to academic and professional resources available only in Farsi. The same graduate may not have access to job opportunities out of Iran because of this language barrier. That is the reason LIS students are encouraged to improve their English as the second language.

Several librarians and aspiring librarians do not have adequate job skills, job opportunities, and motivation. Researchers in library science have documented different challenges in LIS professional practice as follows: lack of training and skills in information technology (IT), lack of adequate IT courses in LIS education programs/curricula, insufficient quality of education, research and professional activities in LIS (Dayyani 2007; Jokar and Hamdipour, 2001; Fattahi, 2005; Mehrad, 2008; Shahbazi et al., 2015), lack of adequate resources/textbooks in the Farsi language, lack of relationships and collaboration with other LIS programs and schools worldwide (Norouzi, 2008), too much focus on practical and professional aspects at the expense of theoretical principles and foundations, lack of research approaches (Hayati, 2004b), the critical need to develop technology-related skills (Tahouri, 2006), the need to create an IT specific institution of higher education, (Fadaei \& Barmar, 2011).

LIS education needs to be continually updated and expanded and all curricula should receive adequate support and resources particularly in the Farsi language. In fact, a large number of courses are specially taught in English especially bat the graduate level. Consequently, there are not enough textbooks in the Farsi at the graduate level (Master's and Ph.D.). LIS education in Iran could be improved both quantitatively (number of LIS departments) and qualitatively (different

\footnotetext{
${ }^{1}$ https://irandoc.ac.ir/
} 
minors/specialties). Further study of the evolution of this field, along with the role of related associations, departments, will certainly reveal more opportunities and challenges. Despite current challenges, LIS in Iran remained one of the most dynamic fields in terms of literature, curricula, programs and academic development in general over the past three decades. This dynamic development has attracted students from other disciplines to LIS. The Iranian LIS community expresses and experiences this dynamism through an annual National LIS congress organized by the Iranian Library and Information Association (LISA).

Iranian higher education institutions are not at the same level in terms of educational resources and facilities. Education received for schools with the best facilities may compare more favorably to opportunities in the USA. Also, a librarian with an undergraduate degree in a subject field and a graduate degree in LIS may compare more favorably to LIS graduates in the USA. Therefore, credentials may have to be evaluated on a case by case basis.

\section{CONCLUSION}

As one of the major cultural and intellectual centers of the world, Iran has long tradition of literary and librarianship. However, modern LIS education is fairly new in Iran and this education is adversely impacted by problems inherent to education systems in developing countries. The use of the Iranian national language for LIS education -- which is legitimate--, restrict access to resources available major world languages such as English. LIS educators and program recognize this limitation that they try to mitigate by providing opportunities for LIS students to learn additional/international languages. On the other hand, an American LIS graduate/librarian who wants to practice LIS in Iran will face some language and cultural challenges.

To be competitive on the international science, LIS education in Iran could be aligned on internationally recognized standards such as the ALA, particular if librarian from Iran should have the opportunity to practice their professional in North American and in other parts of the world where the North American ALA label is recognized. LIS education in Iran should overcome the challenges mentioned above. While maintaining the national language, the teaching and use of international languages such as English should be reinforced with a clear intention of training graduate who can have access to resources and opportunities available at the international level. As things stand right now, LIS credentials of Iranian graduate and professionals can be appreciated on a case by case basis. On the other hand, LIS education in the US could be improved adding more scientometrics skills to the course syllabus to equip librarians with evaluation skills.

\section{AKNOWLEDGEMENT}

Authors gratefully acknowledge anonymous referees and colleagues in Iran and USA for their assistance/comments/support.

\section{REFERENCES}

Akinyotu, A. (1976). A comparative study of education for librarianship in West Africa. International Library Review, 8(4), 493-513.

Alimohammadi, D. (2011). PhD curriculum for librarianship and information science. Book of the month. 166. (Farsi)

American Library Association. (2016), "Become a Librarian", American Library Association, http://www.ala.org/educationcareers/libcareers/become (Accessed May 10, 2018)

Arnove, Robert, and Carlos Torres, eds. 2007. Comparative Education: The Dialectic 
of the Global and the Local. 3rd Ed. New York: Rowman \& Littlefield.

Azarang, A., Asadi, M., Ansari, N., Bani eghbal. N., Horri, A., Hariri, M., \& Haghighi, M. (1993).

Library Science education in Iran. Research on Information Science and Public Libraries, (11), 632.

Afshar, I. (1970). The Newsletter of the Association of Iranian Librarians. Winter. (Farsi)

Ahmadi, S., \& Parirokh, M., (2009). Study of the ability of the LIS discussion group on social capital formation. Journal of Library and Information Science, (47). 19-42.

Azad, A. (1987). Libraries and librarians on the electronic age. Journal of Central Library of Astan-e Quds Razavi, 29-52.

Bereday, George Z.F. (1964). Comparative Method in Education. New York: Holt, Rinehart and Winston.

Board of Trustees of Tehran University. (2006). PhD Program in Librarianship and Informatics. Tehran: Tehran University.

Bouazza, A., \& Nimer, R. (1986). Library education in Tunisia and Jordan: A comparative study. International library review, 18(1), 5-14.

Carnoy, Martin .(1999). Globalization and Educational Reform: What Planners Need to Know. Paris: UNESCO. Available at http://www.unesco.org/iiep.

CheshmeSohrabi, M., Heidari, Gh., \& Azimivaziri, A. (2017). From Librarianship to Information science and knowledge studies: Historiography, Fields of Formation and Development Course of the Field in Iran. Journal of Library and Information Science, 20(2), 3-41. (Farsi)

Crossley, Michael. (1999). "Reconceptualising comparative and international education". Compare; Oxford Vol. 29, Iss. 3, (Oct 1999): 249-267.

Crossley, Michael and Watson, Keith. (2003). Comparative and International Research in Education: Globalisation, context and difference. London and New York: Routledge Falmer.

Dayyani, M.H. (2007). The Future of PhD Library and information science education, Editorial. Journal of Library and Information Science, 10(2), 3-6. (Farsi)

Dayyani, M.H. (2010). The history of library and information science education in Iran. Mashhad: Computer Library Publication. (Farsi)

Ebrami, H. (1975). The starting point: A tangled mess in knowledge studies education. The Letter of Iran Librarians Association. 4(8), 554-543. (Farsi)

Fadaei, Gh.R. (2010). The time has come to establish the college of library science. Iran Book News Agency.

Fadaei, Gh.R, \& Barmar, E. (2011). Faculty of Library and Information Science: Groups, disciplines, trends and offered academic sections. Journal of Academic Librarianship and Information Research, 45(1), 13-26. (Farsi)

FarajPahlou, A. (1994). A review of information technology infrastructure in Iran. Journal of Library and Information Science, 10(4). (Farsi)

Fattahi, R. (2005). New Graduate Program in Library and Information Science: A Report of a Research Project. Journal of Library and Information Science, 8(2), 9-26. (Farsi)

Ghezelayagh, S. (1993). Library Science education in Iran. Interview with Sorayya Ghezelayagh. Research on Information Science and Public Libraries, 3(4), 50-54. (Farsi)

Ginsburg, Mark, and Alison Price-Rom. 2008. "Comparative and International Education." In Encyclopedia of the Social and Cultural Foundations of Education, ed. E. Provenzo. Thousand Oaks, CA: Sage.

Hayati, Z. (2004a). Library and information science education: past, present and future. National Studies on Librarianship and Information Organization. 15(1), 25-41. (Farsi)

Hayati, Z. (2004b). Educational issues in library and information science at universities. Journal of Library and Information Science. 1(25), 26-28. (Farsi)

Hayati, Z. (1996). An Examination of Aspects of The History Of Librarianship And Library Education In 
Iran. Sydney, the University of New South Wales (Ph. D Thesis).

High Council for Educational Planning. (2014). Curriculum for BSc in Information Science and knowledge studies. Tehran: Ministry of Science, Research and Technology, Approved 2014. (Farsi)

High Council for Educational Planning. (2012). Curriculum for BSc in Information Science and knowledge studies, for information management, Tehran: Ministry of Science, Research and Technology, Approved 2012. (Farsi)

High Council for Educational Planning. (2014). Curriculum for BSc in Information Science and knowledge studies, for academic libraries management. Tehran: Ministry of Science, Research and Technology, Approved 2014. (Farsi)

High Council for Educational Planning. (2012). Curriculum for BSc in Information Science and knowledge studies, for public libraries management. Tehran: Ministry of Science, Research and Technology, Approved 2011/31/12. (Farsi)

High Council for Educational Planning. (2014). Curriculum for BSc in Information Science and knowledge studies, for Encyclopedia. Tehran: Ministry of Science, Research and Technology, Approved 2009/31/1. (Farsi)

High Council for Educational Planning. (2014). Curriculum for BSc in Information Science and knowledge studies, for information and science retrieval. Tehran: Ministry of Science, Research and Technology, Approved 2014/09/28. (Farsi)

High Council for Educational Planning. (2014). Curriculum for BSc in Information Science and knowledge studies, for knowledge management. Tehran: Ministry of Science, Research and Technology, Approved 2014/09/28. (Farsi)

High Council for Educational Planning. (2014). Curriculum for BSc in Information Science and knowledge studies, for digital library management. Tehran: Ministry of Science, Research and Technology, Approved 2013/03/02. (Farsi)

High Council for Educational Planning. (2014). Curriculum for BSc in Information Science and knowledge studies, for Scientometrics. Tehran: Ministry of Science, Research and Technology, Approved 2010/05/01. (Farsi)

High Council for Educational Planning. (2014). Curriculum for BSc in Information Science and knowledge studies, for manuscripts management. Tehran: Ministry of Science, Research and Technology, Approved 2013/06/02. (Farsi)

High Council for Educational Planning. (2014). Curriculum for BSc in Information Science and knowledge studies, for Archive studies. Tehran: Ministry of Science, Research and Technology, Approved 2010/08/28. (Farsi)

High Council for Educational Planning. (2014). Curriculum for BSc in Information Science and Knowledge Studies. Tehran: Ministry of Science, Research and Technology, Approved 2009/06/21. (Farsi)

Hopkins, Margaret. (1975) .Ten Years Ago in Iran. Letter from the Association of Iranian Librarians. 8, 4 516-517. (Farsi)

Horry, A. (1993). A review on library and information sciences. Tehran: Board of trustees of the public library of the country. (Farsi)

Horry, A. (1998). An Introduction to Information: Functions and Applications. Tehran: Ketabdar. Hamzepour, M.k. (1998). History of short term library science classes in Iran. Research on Information Science and Public Libraries. 31, 85-87. (Farsi)

Jokar, A., \& Hamdipour, A. (2001). The need for a change in LIS and LIS curriculum. Library and Information Science, 14, 9-26.

Johnson, Catherine (2007), "Library and information science education in developing countries", Volume 39, Issue 2, June 2007, Pages 64-71

Juznic, P., \& Badovinac, B. (2005). Toward library and information science education in the European 
Union: A comparative analysis of library and information science programs of study for new members and other applicant countries to the European Union. New Library World, 106(3/4), 173186.

Kiaei, H. (1970). How library science education in Iran has been established? The Newsletter of Association of Iranian Librarians. Winter. (Farsi)

Kiaei Khouzestani, H. (1997). The system of library science education in Iranian universities in the two periods before and after the Islamic Revolution and the necessary points in improving the status of current situation. Research on Information Science and Public Libraries, 7(2), 35-49. (Farsi)

Kilivand, G. (1999). Digital Library. Research on Information Science and Public Libraries, 9(1). 33-42.

Liu, Y. Q. \& Cheng, X. (2008), (eds), International and Comparative studies in Library and Information Science. A focus on the United State and Asian countries. Lanham, Maryland: Scarecrow Press

Manzon, Maria. (2001). Comparative Education: The Construction of a Field. Hong Kong:

Comparative Education Research Centre, University of Hong Kong and Springer.

Mason, Mark. (2009). "Making educational development and change sustainable: insight from Complexity Theory". International Journal of Educational Development. 29(2). 117-124.

Mehrad, J. (2008). Library and information Science education in Iran is being stagnant. Iran Book News Agency. (Farsi)

Mohammadi, M. (1999). Modern Library science and its challenges. National Studies on Librarianship and Information Organization, 61(1), 138. (Farsi)

Mansourian, Y. (2011). Specialized and interdisciplinary minors in LIS. Book of the month, 166. (Farsi)

Mortezaie, L., \& Naghshineh, N. (2002). A comparative case study of graduate courses in library and information studies in the UK, USA, India and Iran: Lessons for Iranian LIS professionals. Library

Review, 51(1), 14-23. (Farsi)

Norouzi, A. (2008). Proposing a Library and Information Lecturer: Modify the library education program in Iran. Inform and Informing, 8, 10. (Farsi)

Rahadoust, F. (2008). The Philosophy of Library and information science. Tehran: Ketabdar. (Farsi)

Schriewer, J. and Holmes, B., (1988) Theories and Methods in Comparative Education.

Frankfurt am Main, Bern, New York, Paris: Peter Lang.

Shahbazi, R., Fahimnia, F., Hakimzade, R., \& Fadaei, Gh.R. (2015). Analysis of the syllabuses of undergraduate and master's degree programs in the field of information science and knowledge based on emerging job opportunities based on information technology in the global labor market. Journal of Library and Information Science. 18(2), 103-140.

Tahouri, Z. (2006). The need for a revision of library and information education curricula with regard to the new skills needs of librarians and informers. National Studies on Librarianship and Information Organization. 65, 143-162. (Farsi)

Taheri, S. M. and Alaee Arani, M. (2012). A Comparative Study on the Library and Information Science's Branches in USA, Canada, UK, with Iran: Emphasizing on their Effectiveness on the Amount of Scientific Productions at the international level. Quarterly Journal of Knowledge studies. 5(16):83-96. (Farsi). 